\title{
Champions of scholarly communication
}

\author{
By Jinnie Y, Davis
}

\section{A new approach by the NCSU \\ Libraries}

1 decade ago, easy and affordable access to scholarly and research publications seemed threatened as academic libraries initiated massive serials cancellations in the face of rising costs and rampant inflation. Many librarians and faculty became aware of the paradox of the present system: the intellectual product created by scholars is often sold back to their institutions and libraries after they relinquish control to publishers by waiving their own copyrights. Electronic publishing, inirially touted as a way to circumvent the costs and limitations of the traditional scholarly publishing model, came to pose potentially greater restrictions and adclitional costs for libraries and their users. With the recent entry of telecommunications and entertainment industries as major players in the copyright debate, colleges and universities now face a future in which their faculty and students may have fewer rights to the fair use of pullished materials.

In response to this situation, in 1992 the University Library Committee at North Carolina State University estallished a Scholarly Communication Subcommittee of faculry, librarians, administrators, and students. The University Library Committee also succeeded in submitting a resolution passed by the NC State Faculty Senate in 1995, which endorsed the need to increase faculty awareness of issues pertaining to copyright and scholarly publishing. To achieve that goal, the Scholarly Communication Subcommittee has since carried out an active program of educational events, bringing to the NC State campus speakers such as Kenneth Crews (director, Copyright Management Center, Indiana University Purdue University at Indianapolis), Ann Okerson (formerly director, Office of Scientific and Academic Publishing, Association of Research Libraries), and Karen Hersey (intellectual property counsel at MIT).

By learning from these speakers and investigating what other universities were cloing in the area of scholarly communication, the subcommittee originally had clefined as one of its action goals for 1996-97 the promotion of an NC State University "copyright management center." In fall 1996 a subcommittee subgroup consisting of David Zonderman (1)epartment of History, subcommittee chair), 1)avid Broome (associate university counsel), and Jinnie 1)avis (library liaison to the subcommittee) drafted a proposal for such a center. Informed by further discussions with Vice Provost and I)irector of Libraries Susan K. Nutter, the proposal reflected a widening of its scope from a copyright management unit to a Scholarly Communication Center (SCC). Unlike most other universities, in which the copyright management center focuses on guidance to faculty on copyright issues, a broader Scholarly Communication Center would also serve as a source of legal guidance for the library staff and would deal with a wider range of issues, such as database licensing and user privacy.

The library administration's commitment to this effort was embodied in its creation, through internal reallocation of resources, of a full-time position of scholarly communication librarian. Ideally, this position would be filled by a librarian who understands the values of the profession, but who also possesses a J.D. and exper-

Jinnie Y. Datis is assisiant director for Planning and Research at ibe Norlb Carolina State Iniversity libraries; e-mail: jinnie_davis@ucsu.edu 
tise in intellectual property law. Not only ate faculty pleased with the prospect of having an attorney who can help them with questions affecting their teaching and research (e.g., "Do I need to get permission to use material I found on the Internet?"), but the university's Legal Affairs staff also endorses the concept with enthusiasm. Both university counsellors and librarians recognize the tremenclous increase in legal activity from the NCSU Libraries; it is estimated that this position will be able to address about 50 percent of the questions and issues relating to intellectual property that now go to Legal Affairs. The potential for even greater activity is significant, as the NSCU Libraries expands its scope to new areas to ensure that its policies and procedures are in compliance with copyright law: implementation of an electronic reserves system, exploration of the electronic submission of theses and dissertations, and distance learning issues. The Legal Affairs staff welcomes this position as one that-while not acting as official legal counsel for the university-can help extend the support of the Legal Affairs office. The NSCU Libraries, Legal Affairs, and the University Library Committee all agree that the SCC is most appropriately housed in the library, with the scholarly communication librarian reporting to the director of libraries.

Space for the SCC was established on the second floor of the main D. H. Hill Library. In an area newly dedicated to support for learning and research in the digital age, the Scholarly Communication Center will be fortuitously adjacent to the Information Technologies Teaching Center, Learning Technologies Center, Scanning and Digitization Labotatory, the recently created Department for Digital Library Initiatives, and the university's new Center for Teaching and Learning. Interviewing for the scholarly communication librarian began in summer 1997

For the NSCU Libraries, an added incentive for a Scholarly Communication Center is the oppottunity to have a meaningful role in shaping policies related to copyright and fair use at the national and international levels. The first line in the NCSU Libraries' mission statement is: "To define the leading edge of information services, access, and delivery." Following this creed, the SCC was envisioned as taking a leadership role in safeguarding the rights of the scholar and the research library in the scholarly communication process. With a librarian-lawyer leading the Scholarly Communication Center, the NCSU Libraries will be in an excellent position to champion the protection of scholarly communication for the academy.

\section{High Society. Ice Cream Socials. Gang Wars. Fighting Words.}

Human society has countless manifestations and meanings. We track them, and provide you with thousands of references to enhance your research.

Sociological Abstracts (SA), Social Planning/Policy \& Development Abstracts (SOPODA) and Linguistics and Language Behavior Abstracts (LLBA) contain a spectrum of information directly related to your areas of interest and expertise.

Drawing from more than 2,400 journals published in 35 countries, we present abstracts of articles, books and conference papers. Our bibliographic entries will guide you to relevant dissertations and important book and other media reviews. All are expertly indexed and classified for easy access.

SA, SOPODA and LLBA are available in a variety of media: print, online, CD-ROM, and magnetic tape.

Let us help you discover the social worlds and patterns of communication by which we live.

SAI's Web site, located at WwW. socabs.org, contains searchable subsets of the SA, SOPODA, and LLBA databases, hot topics, the Note Us newsletter, and links to other relevant sites and resources.

For more information on our products and services, visit our Web site, or contact us at:
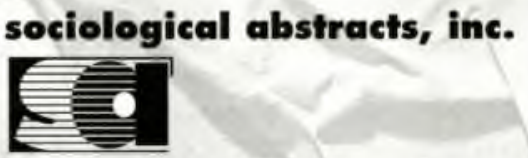

P.0. Box 22206, San Diego, CA 92192-0206

619.695 .8803 Fax 619.695.0416

Internet: socio@cerfnet.com

Web site http://www.socabs.org

SAl products are available in print; online from Knight-Ridder, DIMDI, OCLC and Ovid; on CD-ROM from Silverplatter, EBSCO, Ovid and NISC; and on magnetic tape directly from SAI. For document delivery contact

SOCIOLOGY'Express at

619.695 .8803 or Fax 310.208 .2982$. 